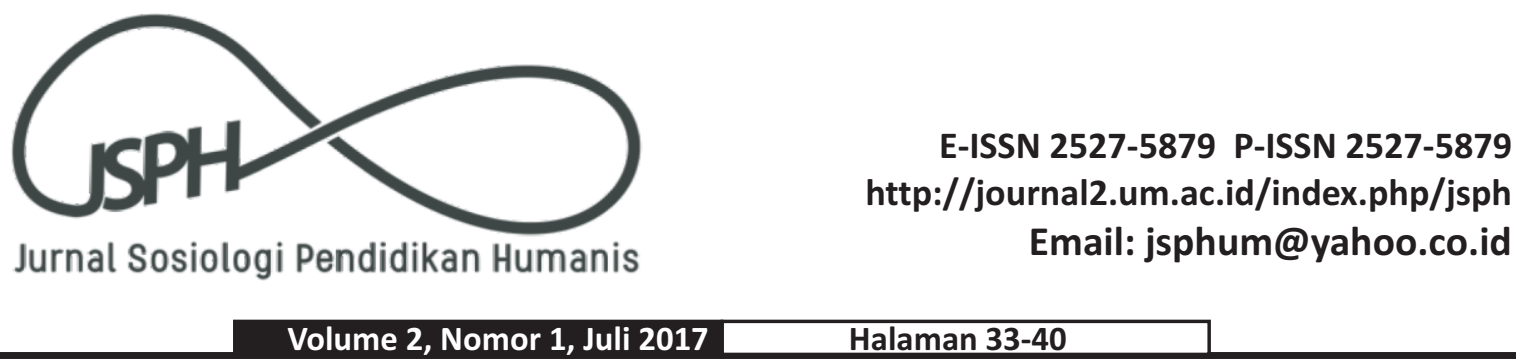

\title{
INTERAKSI BURUH MIGRAN PEREMPUAN SEBAGAI KEKUATAN MODAL SOSIAL
}

\author{
Anggaunitakiranantika \\ Jurusan Sosiologi, Fakultas Ilmu Sosial, Universitas Negeri Malang \\ Email:anggaunita.fis@um.ac.id
}

\begin{abstract}
Abstrak
Migrasi internasional yang terjadi pada buruh migran Indonesia menjadi pusat perhatian berbagai pihak dalam dekade terakhir, permasalahan mengenai ketenagakerjaan, baik di dalam negeri maupun di luar negeri mulai banyak terangkat ke permukaan dengan pemberitaan secara meluas di media.BMI yang bekerja di luar negeri, baik kategori legal maupun yang ilegal lebih banyak melibatkan perempuan di Propinsi Jawa Timur, salah satunya berasal dari Kabupaten Tulungagung. Di Negara Hongkong jumlah BMI asal Propinsi Jawa Timur paling banyak, yakni mencapai sekitar 170.000 orang, disusul Taiwan sekitar 160.000, dan Malaysia sekitar 130.000 orang.Penelitian dilakukan untuk menganalisis keberanian pada perempuan untukmenjadi buruh migranyang didasari oleh interaksi sosial. Analisis pada interaksi juga dilakukanuntuk mengetahui modal sosial yang tercipta di kalangan buruh migran Indonesia yang berasal dari Kabupaten Tulungagung. Penelitian dilakukan dengan metode kualitatif dengan teknik purposive di Kabupaten Tulungagung. Keterlibatan perempuan di Kabupaten Tulungagung menjadi Buruh Migran Indonesia dilakukan atas dasar keberanian dalam merubah nasib hidupnya dan melawan fatalisme sebagimana melekat pada masyarakat desa. Interaksi sosial yang dilakukan oleh buruh migran Indonesia melalui komunikasi virtual dengan perantara media sosial adalah bentuk dari Geometry of social space dalam kajian interaksi Simbolik. Interaksi sosial inilah yang menjadi modal utama dalam penguatan jaringan di dalam masyarakat sehingga buruh migran Indonesia mampu membentuk masyarakatnya sendiri dalam sistem sosial yang lebih luas.
\end{abstract}

Kata Kunci: Buruh Migran; Indonesia; Interaksi Sosial; Modal Sosial; Perempuan

THE INTERACTION OF FEMALE MIGRANT WORKERS AS A FORCE OF SOCIAL CAPITAL

\begin{abstract}
International migration on Indonesia migrant worker attracts many people on last decades. Workforce labor problems, either in-country or abroad has begun rose into society, announced by mass media. Indonesia worker who get jobs abroad, whether on legal sector or on illegal, was involved women in East Java Province. Furthermore, some of them comes from Tulungagung Regency. On Hongkong, the number of Indonesia migrant worker is all the much, attained on 170.000 peoples, Next on Taiwan approximately 160.000 peoples, Then Malaysia on 130.000 peoples. Research was conducted for analyze women courage to join as migrant worker based on social interaction. Analysis of interaction was used for detecting social capital among Indonesia migrant workers who comes from Tulungagung Regency. Research was done by qualitative methods, with purposive technique in Tulungagung Regency. To sum up, basically, women involvement on Indonesia migrant workers who comes from Tulungagung Regency has found from their willingness for quality of life betterment and fought patriarchy culture valiantly as well as their goal upon other villagers. Women migrant workers has occurred social interaction by virtual communication through the medium of social media. It was a form of Geometry of social space on symbolic interaction aspect. Moreover, this also mentioned if the priority for network streghtening among society are social interaction. The stronger the interaction, the broader the society was constructed on women migrant workers on social system extensively.
\end{abstract}

Keywords: Indonesia; Migrant Workers; Social Capital; Social Interaction; Women 


\section{LATAR BELAKANG}

Buruh Migran Indonesia atau yang sering dikenal dengan istilah BMI atau TKI merupakan pekerjaan yang dimiliki oleh sebagian besar perempuan yang berdomisili di Propinsi Jawa Timur hingga tahun 2016. Propinsi Jawa Timur dikenal sebagai salah satu propinsi tertinggi sebagai pemasok kebutuhan akan buruh migran ke beberapa kawasan Asia-Pasifik, seperti HongKong, Taiwan, Korea, Malaysia, Singapura dan Brunei Darussalam. Berdasarkan data yang diperoleh dari BNP2TKI hingga bulan Januari 2016, beberapa kabupaten atau daerah yang terdapat di Propinsi Jawa Timur yang menjadi kantong atau wilayah terbanyak akan perempuan yang berstatus sebagai Buruh Migran Indonesia adalah Kabupaten Tulungagung (1.657 penduduk), Kabupaten Banyuwangi (1.323 penduduk), Kabupaten Blitar (1.289 penduduk), Kabupaten Ponorogo (1.219 penduduk) dan Kabupaten Malang (632 penduduk). Jumlah penduduk yang didapat di atas adalah jumlah penduduk yang sifatnya kumulatif hingga Bulan Januari 2016 yang memutuskan untuk menjadi Buruh Migran Indonesia, jadi jumlah tersebut bukanlah jumlah keseluruhan penduduk yang memutuskan untuk menjadi Buruh Migran Indonesia.

Berdasarkan hasil penelitian yang telah dilakukan sebelumnya, diketahui bahwa yang menjadikan perempuan memilih merantau menjadi Buruh Migran Indonesia disebabkan oleh beberapa hal, yakni orientasi pada uang. Banyaknya beban yang harus ditanggung untuk membiayai hidup keluarga dan orangtua menyebabkan masyarakat yang didominasi oleh perempuan menjadi buruh migran (Anggaunitakiranantika, 2015:18). Dengan demikian, diharapkan setelah menjadi para Buruh Migran Perempuan, kualitas hidup akan menjadi lebih baik dibandingkan dengan sebelumnya, yang ditandai dengan kepemilikan secara fisik, dalam bentuk harta benda perhiasan emas, investasi berbentuk rumah, tanah, kendaraan bermotor ataupun hewan ternak.Berdasarkan data yang didapat dari BNP2TKI hingga bulan Januari 2016, adalah sebagai berikut:

Domestic Worker atau Penata Laksana Rumah

Tangga: 11.954 penduduk

Caregiver atau Perawat bagi anak ataupun

Lansia: 8.335 penduduk

Housekeeper atau Pekerja dalam Rumah

Tangga: 1.105 penduduk

Faktor utama menjalankan profesi tersebut dikarenakan selama mereka tinggal di Indonesia, perempuan Indonesia selalu dibiasakan dengan budaya patriarkhi dan melakukan peranan penting dalam sektor domestik,sehingga dalam memjalankan peranan tersebut sebagai sebuah profesi yang menghasilkan uang, dirasa dunia tersebut adalah dunia yang sudah lazim dilakukan oleh perempuan Indonesia dan bukanlah hal yang membutuhkan sebuah keahlian khusus.

Penelitian ini dilakukan dengan memperhatikan kelangkaan pada kajian yang menitikberatkan kehidupan Buruh Migran Perempuan dengan memperhatikan hubungan sosial yang terjadi diantara komunitas yang terbentuk pada Buruh Migran Perempuan. Hubungan sosial yang terjadi ini terbentuk sebagai cikal bakal modal sosial yang nantinya digunakan sebagai pembentuk ikatan untuk mengokohkan identitas pada Buruh Migran Perempuan. Penelitian mengenai Buruh Migran Perempuan bukanlah hal yang baru namun kajian yang banyak dilakukan adalah pada remitansi dan dampak sosial ekonomi yang melingkupinya, dalam tulisan ini, hubungan sosial sebagai pembentuk jaringan sosial dalam kehidupan Buruh Migran Perempuan akan dibahas secara rinci dengan mengesampingkan analisis atau perhatian selain aspek remitansi. Tujuan dari penelitian adalah untuk menganalisis interaksi sosial yang dilakukan oleh wanita yang berasal dari Kabupaten Tulungagung dalam komunitas Buruh Migran Perempuan di Negara tujuan Asia-Pasifik seperti Taiwan, Hongkong, Malaysia dan Singapura menggunakan kajianinteraksi simbolis dan mengetahui kekuatan modal sosial yang telah terbentuk berdasarkan interaksi yang dilakukan oleh buruh migranperempuan yang masih terbatas untuk diteliti dalam kajian Sosiologi.

\section{METODE PENELITIAN}

Dalam metodologi penelitian, terdapat sebuah paradigma yang diartikan sebagai anggapananggapan meta-teoritis yang paling mendasar yang menentukan kerangka pikir, cara mengandaikan dan cara bekerjanya para penganut teori sosial yang menggunakannya (Neuman, 2000:67) Di dalamnya tersirat adanya kesamaan pandangan yang mengikat sekelompok penganut teori dalam cara pandang dan cara kerja yang sama dalam batas-batas pengertian yang sama pula. Jika para ilmuwan sosial telah menggunakan paradigma tertentu, maka berarti memandang dunia dalam suatu cara yang tertentu pula.

Paradigma merupakan cara mengelompokkan cara berpikir sesesorang dalam suatu teori sosial dan merupakan alat untuk memehami mengapa pandangan-pandangan dan teori tertentu dapat lebih menampilkan sentuhan pribadi dibanding yang lain. Demikian juga alat untuk memetakan perjalanan pemikiran teori sosial seseorang terhadap persoalan sosial. 
Dalam penelitian ini, menggunakan pendekatan subyektivitas dalam analisis sosialnya, sehingga hubungan dengan sosiologi keteraturan bersifat tersirat. Dalam penelitian ini ingin memahami kenyataan sosial menurut apa adanya, mencari sifat yang paling dasar dari kenyataan sosial, yaitu mengenai hubungan sosial atau interaksi yang dilakukan oleh seseorang dalam komunitas Buruh Migran Indonesia menurut pandangan subyektif dan mengetahui kesadaran seseorang yang langsung terlibat dalam peristiwa sosial bukan menurut orang lain yang mengamati. Pendekatannya cenderung nominalis, anti-positivis dan idiografis. Kenyataan sosial,seperti halnya tindakan sosial atau interaksi yang dilakukan secara sengaja muncul karena dibentuk oleh kesadaran dan tindakan seseorang. Karenanya mereka berusaha menyelami jauh ke dalam kesadaran dan subyektivitas pribadi manusia untuk menemukan pengertian apa yang ada di balik kehidupan sosial.

Penelitian ini mengambil setting sosial di KabupatenTulungagung, Jawa Timur.Dalam rangka penelitian ini, peneliti melakukan studi pendahuluan ke beberapa tempat seperti Komunitas Ex- Buruh Migran Perempuanyang tersebar di Kabupaten Tulungagung,Kantor Kecamatan di KabupatenTulungagung dan Balai desa dan/atau Kantor Kelurahan di wilayah Kabupaten Tulungagung.Penentuan lokasi berujung hingga peneliti menemukan wanita penduduk asli dari wilayah kecamatan di Kabupaten Tulungagung yang berstatus menikah dan berencana untuk menjadi buruh migran dan atau telah menjadi mantan Buruh Migran Perempuan yang tidak kembali lagi ke Negaranegara tujuan seperti Hongkong, Taiwan, Malaysia dan Singapura.Berdasarkan data yang didapatkan dari Disnakertrans Kabupaten Tulungagung pada tahun 2016, Kantong buruh migran yang tersebar di wilayah Kabupaten Tulungagung meliputi 4 Kecamatan terbanyak; yaitu Kecamatan Besuki, Kecamatan Kalidawir, Kecamatan Bandung, dan Kecamatan Campurdarat.Dengan pertimbangan bahwa penelitian ini memerlukan suasana yang kondusif antara subyek dan peneliti maka sasaran ditentukan pada pelaku yang berdomisili asal di KabupatenTulungagung.Selain itu, diasumsikan bahwa masyarakat asli Kabupaten Tulungagung memiliki karakter yang terbuka sehingga memudahkan peneliti untuk menggali informasi mengenai interaksi sosial dalam komunitas Buruh Migran Indonesia Migran didapatkan lebih dalam secara objektif dan dipandang dari sudut bahwa informan memang pernah melakukan migrasi internasional ke negara lain di negara asiapasifik.

Informan dalam penelitian ini adalah perempuan atau wanita yang telah berkeluarga yang berasal dari wilayah kecamatan terpilih di Kabupaten Tulungagung yang menjadi buruh migran dengan tujuan kerja adalah negara di asia pasifik seperti Hongkong, Taiwan, Singapura dan Malaysia. Penentuan informan ini tidak dibatasi pada jenis atau sektor bidang pekerjaannya untuk mendapatkan kekayaan informasi.Yang dibatasi hanyalah lama berada di Negara tujuan, minimal 2 tahun atau menghabiskan masa kontrak yang dimaksudkan untuk mengetahui bahwa wanita tersebut telah mampu menguasai pekerjaan di bidangnya dan mampu melakukan adaptasi di Negara tujuan tempat ia bekerja.Subyek penelitian diambil menggunakan teknik purposive sampling dalam penulisan lapangan, nama - nama mereka akan disamarkan. Penentuan subyek diperoleh dari informan kunci, yaitu ketua komunitas atau perangkat desa di Kabupaten Tulungagung yang dianggap mengenal secara personal terhadap perempuan yang pernah menjadi buruh migran negara lain di kawasan Asia-pasifik. Untuk memudahkan penelitian, penentuan informan juga dilakukan peneliti dengan pendekatan secara personal terhadap mantan buruh migranperempuan, baik yang akan atau pernah bekerja di Hongkong, Taiwan, Malaysia dan Singapura tanpa ada perbedaan. Upaya ini dilakukan supaya terjalin hubungan yang kondusif antara subyek dan peneliti agar diperoleh informasi yang maksimal.

Berdasarkan uraian di atas, informan dalam penelitian ini diperoleh sebesar jumlah subyek dalam penelitian ini tidak ditentukan secara baku karena dalam studi ini jumlah subyek penelitian tidak dapat dijadikan ukuran utama, yangmengerucut pada 13 informan yang berasal dari daerah berbeda di Kecamatan yang ada di Kabupaten Tulungagung. Selain subyek penelitian, pendekatan pada sejumlah informan kunci juga dilakukan untuk mendapatkan data dan informasiyang dibutuhkan.

\section{HASIL DAN PEMBAHASAN \\ Keberanian Menjadi Buruh Migran Indonesia}

Buruh Migran Indonesia yang bekerja di luar negeri, seperti Malaysia, Hongkong, Taiwan, ataupun Singapura sebagian besar diidentifikasi sebagai sosok wanita yang berani.Berani dalam konteks ini adalah mampu menghilangkan perasaannya sebagai bagian masyarakat patriarkhi yang menurut adat budaya Jawa harus menjalankan kodratnya secara domestik. Berani disini diafiliasikan dengan kemampuan seseorang untuk meninggalkan keluarga di 
kampung halaman.

Keberanian para wanita dalam pengambilan keputusanmenjadi Buruh Migran Indonesia seolah tidak menghiraukan berbagai masalah aktual yang seakan tak pernah berhenti dibahas. Sepanjang tahun dalam dekade ini, Pemerintahan Indonesia selalu dipusingkan dengan permasalahan buruh migran, antara lain banyaknya kekerasan yang terjadi dinegara pengimpor buruh migran, dan kasus-kasus pendeportasian para Buruh Migran Indonesia. Fenomena ini menjadi sorotan bagi pemerintah saat ini, tetapi berbagai solusi yang telah di tawarkan oleh pemerintah tidak mengurangi jumlah buruh migran di Indonesia. Hal tersebut disebabkan karena pemerintah tidak pernah dengan serius memperhatikan analisis kebutuhan yang menjadi penyebab keterlibatan wanita menjadi buruh migran Indonesia sebagai pilihan profesi.

Berdasarkan hasil wawancara yang telah dilakukan, keterlibatan wanita menjadi buruh migran Indonesia antara lain kurangnya lapangan pekerjaaan yang ada di daerah asal, hal tersebut disebabkan oleh semakin sempitnya lahan lahan pertanian di desa yang saat ini mulai bergeser memasuki sektor industri, rendahnya SDM (Sumber Daya Manusia) pada penduduk lokal wanita yang ada di Kabupaten Tulungagung sehingga tidak bisa mendapatkan pekerjaan dengan pendapatan tinggi. Rendahnya kualitas SDM ini juga sangat nampak pada jenis penguasaan skill yang dimiliki oleh penduduk wanita di Kabupaten Tulungagung yang tidak lepas dari sektor domestik seperti memasak dan membereskan rumah yang kurang dianggap sesuai dengan kebutuhan industri yang ada di Kabupaten Tulungagung.Kurangnya SDM (Sumber Daya Manusia) dikarenakan minimnya pendidikan, kurang sadarnya pentingnya pendidikan bagi masa depan mereka. Temuan dalam penelitian juga mengerucut pada banyaknya perkawinan muda yang masih dilakukan sebagian penduduk di Kabupaten Tulungagung yang menjadi informan, sehingga tuntutan akan pemenuhan dalam keluarga juga semakin meningkat.

Lapangan pekerjaan semakin langka di Kabupaten Tulungagung didukung dengan kurangnya SDA (Sumber Daya Alam) diwilayah tersebut yang kurang mendukung, karena secara geografis informan yang diteliti mendiami wilayah perbukitan kapur sehingga pengolahan lahan dan pemanfaatan lahan kurang menghasilkan dan dipandang tidak mencukupi kebutuhan hidup bagi informan.

Perubahan tempat bekerja dari desa secara drastic ke Negara lain atau perubahan pekerjaan dari agraris ke industri yang memiliki kebiasaan, simbol-simbol, nilai dan norma yang berbeda, mensyaratkan adanya proses adaptasi yang meliputi seluruh tindakan sosial-ekonomibudaya seorang migran. Optimalisasi prestasi dan produksi dalam bekerja sangat ditentukan kemampuan migran dalam beradaptasi (Ford, Michelle, Parker,Lyn, 2008:12). Selain berdasarkan kedua hal penting yang telah dijelaskan, pemicu buruh migran untuk bekerja ke luar negeri adalah kuatnya modal sosial yang dimiliki oleh individu-individu buruh migran itu sendiri. Berdasarkan hasil penelitian, yang dilakukan oleh peneliti banyak terdapat kecenderungan yang terjadi pada buruh migran di Indonesia khususnya di Kabupaten Tulungagung. Modal sosial juga menjadi salah satu penentu yang sangat penting bagi calon buruh migran dan ex-buruh migrandalam keterlibatannya pada migrasi internasional.

Hal lain yang membuat partisipasi wanita melakukan migrasi internasionalmenjadi terus berkembangadalah kuatnya jaringan sosial yang ada di kalangan buruh migran indonesia. Kehadiran para buruh migran Indonesia yang pulang secara periodik, membawa cerita, gaya dan penampilan yang disimbolkan sebagai identitas individu yang maju dan modern. Simbol-simbol itu dinilai sebagai indikator kemajuan status ekonomi maupun sosial di masyarakat. Disadari atau tidak, gambaran mengenai perkembangan dalam gaya hidup ataupun modernisasiikut mendorong warga desa yang lainnya untuk bermigrasi. Pada titik ini keberadaan jaringan sosial cenderung menguat. Para migran terdahulu, baik yang masih berada di negara lain ataupun yang telah menjadi ex-buruh migrandapat menjadi titik pembentuk jaringan sosial yang memperkuat psikologis warga desa lain di Kabupaten tulungagung untuk ikut bermigrasi sebagai buruh migran perempuan.

\section{Interaksi Buruh Migran Sebagai Modal Sosial}

Modal sosial yang dimaksud adalah adanya sebuah jaringan buruh migran yang ada di bebrapa negara tujuan, seperti Negara Hongkong, Negara Taiwan, Negara Singapura ataupun Negara Malaysia. Jaringan-jaringan sosial tersebut terbentuk melalui keluarga, tetangga, dan teman-teman semasa mereka sekolah. Hal ini dibuktikan dengan petikan wawancara yang peneliti lakukan dengan informan yang bernama Murna, 32 tahun sebagai berikut.

"aku wani budal lungo nang luar negeri iki mergo bondo nekat seng sepisan seng kepindone iki akeh konco-konco ku seng lungo neng kono sukses, seng ketelu mbak yu wes enek seng kerja nek kono disek".

Dalam bahasa Indonesia artinya" Saya berani berangkat kerja ke luar negeri, yang pertama 
punya modal tekat, yang kedua karena banyak teman-teman saya yang bekerja disana banyak yang sukses, yang ketiga karena kakak saya sudah ada yang bekerja disana.

Selanjutnya dalam wawancara dengan informan yang lain, peneliti selanjutnya menanyakan hal yang berkaitan dengan ungkapan informan diatas tentang pembentukan modal sosial atau membentuk sebuah jaringan oleh para buruh migran. Pertanyaan yang dilontarkan oleh peneliti sebagai berikut.

Peneliti: "la ngono kuwi mbak neng kono (Hongkong) kuwi ya iso ketemu konco-konco ne samean utawa ambek mbak saman?"

Dalam bahasa Indonesia kalau disana mbk itu apa bisa bertemu dengan teman-teman atau saudara juga?.

Informan (Lely, 21 tahun) menjawab: "yo iso mbak nek kono iki seminggu pisan ya libur dina sabtu ambk minggu mbk dadi libur iku wongwong indo seng buruh nek kono podho dolan neng taman, dadi ya iso ketemu mangan bareng utawa belanja bareng, penak mbk nek kono kuwi iso libur gak koyok kerjo nek Indonesia mbak".

Dalam bahasa Indonesia artinya ya bisa mbak satu minggu itu disana (Negara Hongkong) ada liburnya yaitu hari sabtu atau minggu, jadi kalau libur begitu orang-orang Indonesia yang bekerja disana atau buruh migran pergi ke taman untuk sekedar bertemu sesama buruh migran atau makan bareng bahkan belanja bersama.

Wawancara yang dilakukan oleh peneliti pada informan yang bekerja sebagai buruh migran, misalnya di Negara Hongkong ini menyatakan bahwa cara membentuk modal sosial dengan membangun jaringan-jaringan antara buruh migran. Jaringan-jaringan tersebut dibentuk dimana tempat atau negara bekerja atau negara tujuan mereka bekerja. Dengan adanya jaringanjaringan antara buruh migran tersebut sangat berarti bagi mereka. Jaringan-jaringan tersebut tidak hanya diantara buruh migrant tetapi juga agensi yang ada disana. Agensi di sana (misalnya: Negara Hongkong) sangat membantu para buruh migran yang ada di negara tujuan. Peran agensi disini sebagai penyalur komunikasi antara buruh migran. Dengan modal sosial yang berupa jaringan yang dimiliki antara para buruh migran itulah yang menjadi modal utama dalam interaksi sosial yang dilakukan oleh calon migran.

Dengan semakin mobile suatu teknologi, semakin mudah diakses dan dimilikinya suatu teknologi, sosial media sudah semakin menjadi darah daging bagi orang jaman sekarang. Dalam kelompok yang lebih besar, kelompok-kelompok kecil calon buruh migran sudah dapat dengan mudah bergabung baik untuk membentuk jaringan sosial baru maupun menggabungkan diri dengan kelompok-kelompok buruh migran yang lama.

Interaksi yang dilakukan dalam bentuk jaringan para buruh migran juga dilakukan dengan memanfaatkan media sosial untuk memudahkan berkomunikasi, media sosial yang digunakan salah satunya adalah facebook, bahkan mereka membuat grup dalam akun facebook tersebut yang bisa diakses oleh siapa saja dengan tujuan mengembangkan interaksi seluas-luasnya untuk membangun keakraban dan mengembangkan jaringan lebih baik di kalangan buruh migran Indonesia.

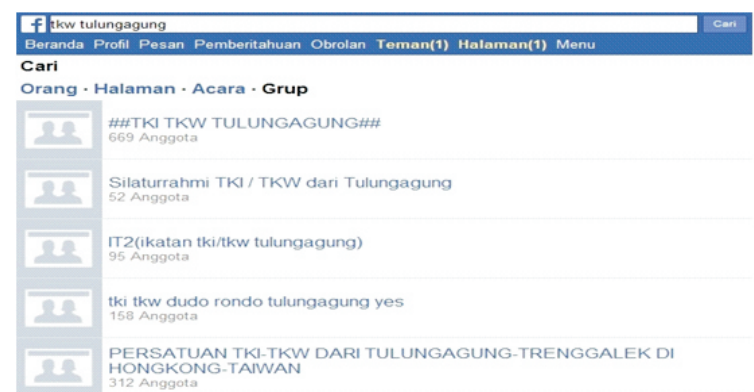

\section{Gambar 1. Media sosial TKW Tulungangung} (Sumber: Media sosial facebook)

Pada media sosial facebook, mereka membentuk komunitas atau grup berdasarkan daerah asal mereka dan tempat tujuan mereka bekerja menjadi buruh migran, seperti yang terlihat pada gambar diatas.Keuntungannya kalau buruh migran membuat satu komunitas dalam media sosial, mereka akan lebih mudah melakukan interaksi sosial diantara kalangan buruh migran, menemukan saudara atau teman yang sama-sama bekerja di sebuah negara tujuan, seperti contohnya Negara Hongkong. Jaringan antara para buruh semakin berkembang dan semakin luas, hal tersebut terbukti bahwa mereka mampu membangun modal sosial dalam hal ini salah satu membuka atau membentuk sebuah jaringan. Dengan modal tersebut mereka lebih yakin untuk berangkat bekerja sebagai buruh migran, karena mereka disana sudah tidak merasa asing dan sendiri, walaupun tidak kenal dengan mereka tapi mereka berasal dari kota atau negara

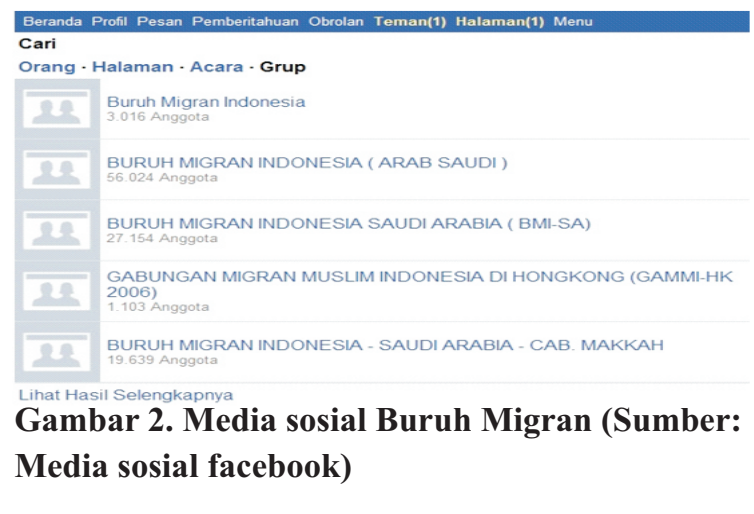


yang sama membuat mereka merasa satu keluargaBeberapa grup buruh migran yang sering menjadi ajang berkumpul dan membentuk jejaring sosial antara lain grup berdasarkan daerah asal, seperti: Tulungagung, Trenggalek, Blitar, Banyuwangi dan sebagainya.

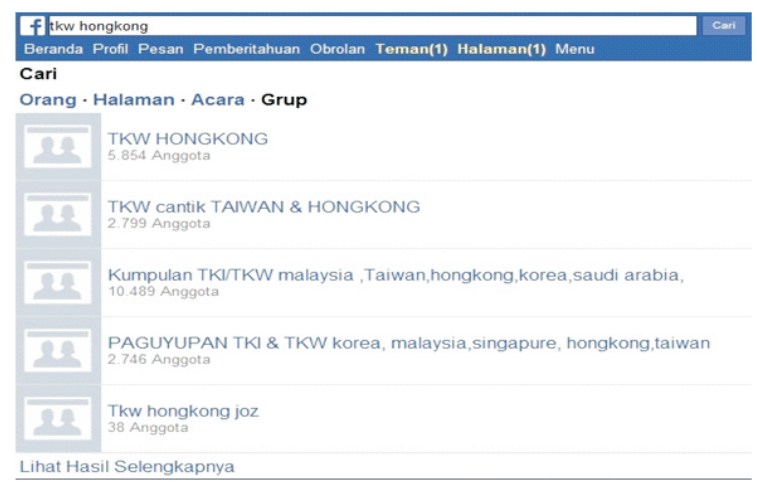

\section{Gambar 3. Media sosial TKW Hongkong}

(Sumber: Media sosial facebook)

Keterkaitan jaringan dan kelompok merupakan aspek vital dari modal sosial. Jaringan sosial terjadi berkaitan dengan adanya keterkaitan antara individu dengan kelompok. Keterkaitan terwujud dengan di dalam beragam tipe kelompok pada tingkat lokal maupun tingkat lebih tinggi. Grup atau fanspage di Facebook telah menjadi dunia kedua di mana orang berkumpul saling bersosialisasi satu sama lain. Keterbukaan dan kemudahan akses sosial media telah membuat grup dan fanspage di Facebook menjadi salah satu modal sosial yang cukup kuat bagi calon buruh migran baik untuk mendapatkan informasi tentang negara tujuan maupun mencari serta membuat jaringan sosial di antara buruh migran.

Jaringan sosial media ini sering digunakan sebagai sarana berkumpul, berdiskusi, tanya jawab, ataupun curhat. Beberapa jaringan sosial media yang sering menjadi sarana interaksi sosial dan dipergunakan sebagai ajang berkumpul buruh migran Indonesia ini antara lain grup yang terbentuk melalui WhatsApp, grup Blackberry Messenger, fanspage Facebook atau grup Facebook. Beberapa grup dan fanspage Facebook bersifat terbuka yang dapat dengan mudah untuk diakses dan dimasuki oleh siapapun.Grup atau fanspage di Facebook telah menjadi dunia kedua di mana orang berkumpul, melakukan interaksi dan proses sosial antara satu sama lain. Keterbukaan dan kemudahan akses sosial media telah membuat grup dan fanspage di Facebook menjadi salah satu modal sosial yang cukup kuat bagi calon buruh migran baik untuk mendapatkan informasi tentang berbagai seluk beluk kehidupan buruh migran di Negara tujuan, meningkatkan solidaritas diantara buruh migran Indonesia hingga meningkatkan jaringan sosial di antara satu sama lain.
Dari hasil observasi yang dilakukan, dalam Grup Komunitas Buruh Migran, pola komunikasi yang tercipta secara aktif dilakukan oleh buruh migran yang telah bekerja di Negara Hongkong, Singapura, Arab Saudi dan Korea Selatan dibandingkan buruh migran di negara lainnya. Postingan atau penyampaian informasi yang dilakukan juga lebih cenderung pada informasi mengenai kegiatan sehari-hari selama menjalankan profesi sebagai pekerja migran.Unggahan berupa foto atau kata-kata tersebut baru mendapat respon atau komentar dari teman lainnya, termasuk calon buruh migran yang masih berada di Indonesia. Hampir setiap hari, berbagai unggahan masuk dalam grup Buruh Migran memberikan informasi mengenai apa yang terjadi dalam dunia keseharian yang dialami oleh Buruh Migran Indonesia.

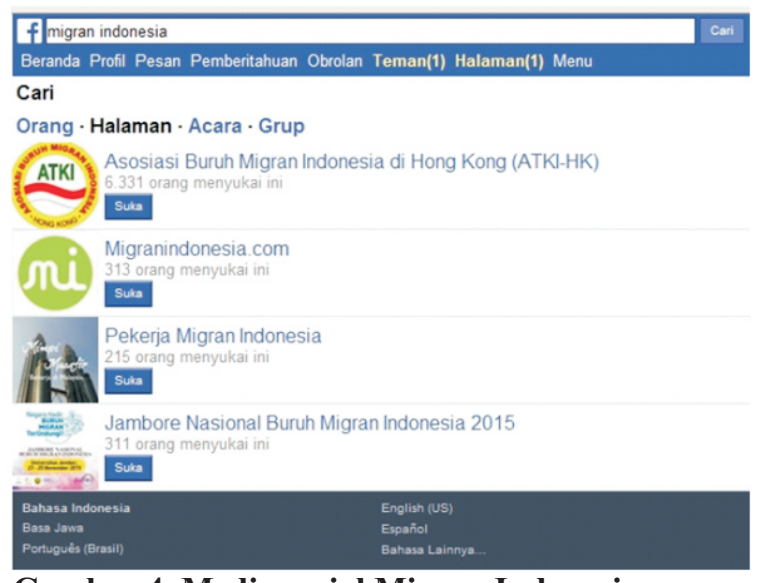

Gambar 4. Media sosial Migran Indonesia

(Sumber: Media sosial facebook)

\section{Kajian Interaksionisme Simbolik Dalam Modal Sosial Buruh Migran Indonesia}

Interaksionalisme simbolik yang digunakan pertama kalinya oleh Herbert Blumer, pada dasarnya merupakan satu perspektif psikologi sosial. Perspektif ini memusatkan perhatiannya pada analisa hubungan antar-pribadi. Individu dipandang sebagai pelaku yang menafsirkan, menilai, mendefinisikan, dan bertindak. Dalam kajian interaksi simbolis selanjutnya juga dilakukan oleh Georg Simmel yang menaruh perhatian khusus tentang pemahaman akan bentuk-bentuk dan konsekuensi berbagai bentuk interaksi yang berbeda-beda. Salah satu bidang yang menjadi pusat perhatiannya adalah hubungan antara individu dan masyarakat.Di dalam bukunya yang terkenal 'Conflict and The Web of Group Affliations',Simmelmengatakan bahwa kepribadian manusia timbul dari dan dibentuk oleh kelompok atau budaya dimana seseorang hidup. Keberadaan seseorang, bagaimana dia berpikir dan bertingkah laku dipengaruhi keanggotaannya dalam kelompok tertentu (Wallace, R.A. and Wolf, A., 1980:78). 
Kesadaran individu merupakan sumber awal bagi Simmel dalam mengkaji lebih jauh tentang interaksi sosial, ia telah melakukan teoretisasi masalah modernitas dengan penekanan pada perkembangan pesat dari ilmu, teknologi, pengetahuan obyektif, berikut diferensiasinya di satu sisi dan erosi budaya subyektif di sisi lain. Konflik dan krisis kebudayaan modern oleh Simmel digambarkan dalam bentuk pemiskinansubyektivitas yang disebutnya endemi atrophy (terhentinya pertumbuhan budaya subyektif) karena hypertrophy (penyuburan budaya obyektif). Simmel berusaha menjelaskan adanya ketimpangan budaya individu atas manusia sebagai subjeknya dibandingkan dengan perkembangan media atau sarana kehidupan yang mengurangi peran aktif manusia dalam berkarya. Sehubungan dengan fenomena endemi antrophy interaksi menjadi salah satu pokok pemikiran dalam teori Simmel.

Masyarakat, kemudian, dapat diartikan sebagai sejumlah individu yang terhubungkan melalui interaksi. Interaksi ini dapat menjadi mengkristal sebagai bidang permanen. Hubungan ini, atau bentuk sociation, sangat penting karena mereka menunjukkan bahwa masyarakat bukan merupakan substansi, tetapi sebuah peristiwa, dan karena bentuk-bentuk sociation mengatasi individu atau dualisme sosial (individu terlibat dengan satu sama lain dan dengan demikian merupakan sosial). (Poloma, M. 1993:110)

Sedangkan interaksi sosial sendiri menurut Georg Simmel memiliki point-point tersendiri yang menurutnya merupakan hal yang perlu untuk disertakan dalam teori-teorinya, Simmel mengungkapkan bahwa interaksi menurut bentuknya dapat dibedakan menjadi berikut yaitu: Subordinasi (ketaatan), Superordinasi (dominasi), Hubungan seksual, Konflik, dan Sosiabilita (interaksi yang terjadi demi interaksi itu sendiri dan bukan untuk tujuan lain). sedangkan menurut tipenya meliputi: interaksi yang terjadi antar individu-individu, interaksi yang terjadi antar individu-kelompok, dan interaksi yang terjadi antar kelompok-individu.

Pada keadaan yang sama yaitu kehidupan dengan interaksi dan komunikasi dapat menumbuhkan kemungkinan-kemungkinan tertentu, dimana hal tersebut memiliki dampak positif dan negatif, ada pada suatu saat seseorang merasakan kedekatan, kekompakan, dan kebersamaan baik secara pribadi maupun kelompok.Adanya kontak merupakan faktor yang mendorong terjadinya komunikasi, kontak tersebut terdiri dari kontak secara langsung maupun secara tidak langsung ( melalui media), dan komunikasi itu sendiri adalah gambaran dari adanya interaksi dalam hidupnya dengan orang lain. Simmel juga memusatkan pemikirannya mengenai relasi (hubungan), khususnya interaksi antar pemeran sadar dan tujuannya adalah melihat besarnya cakupan interaksi yang mungkin sepele namun pada saat lain sangat penting. Menurut Simmel interaksi timbul karena kepentingan-kepentingan dan dorongan tertentu. (Johnson, D.P., 1986:54)

Sebagaimana yang nampak dalam penelitian ini bahwa yang dikaji adalah interaksi sosial yang dilakukan mantan Buruh Migran Indonesia dengan lingkungannya, hal ini sangat nampak pada komunikasi yang sangat intens melalui kontak secara tidak langsung dengan perantara media sosial, seperti Facebook. Interaksi yang dilakukan oleh para buruh migran dan mantan Buruh Migran Indonesia yang telah kembali dari beberapa negara tersebut dilakukan secara dinamis di Kabupaten Tulungagung, dengan melalui posting status dan membalas komentar yang dilakukan hampir setiap hari. Interaksi sosial yang nampak dalam kehidupan keseharian pada kehidupan mantan Buruh Migran Indonesia merupakan hasil dari kemampuan personal untuk mampu menafsirkan dunia sekitarnya menggunakan perantara media komunikasi sebagai modal sosial yang dimilikinya.

Pandangan Georg Simmel bagi perspektif ini sangat berlaku dalam mengkaji fenomena interaksi sosial pada buruh migran Indonesia yang berasal dari Kabupaten Tulungagung dari ide dasarnya tentang masyarakat yang ia pandang sebagai suatu sistem interaksi, yang menempatkan individu sebagai bagian terpenting dari sistem sosial, dimana pada level individu inilah proses interaksi terjadi dan kemudian menggema hingga membentuk masyarakat. Istilah yang digunakan Simmel untuk melukiskan proses ini adalah "geometry of social space. ."Menurut Simmel masyarakat adalah suatu bentuk interaksi sosial yang terpola seperti halnya jaring laba-laba. Dan ini merupakan tugas dari sosiolog untuk meneliti bentuk interaksi sedemikian itu bagaimana mereka terjadi dan mewujud di dalam kehidupan sejarah dan seiring budaya yang berbeda. Sosiologi adalah "master science" dimana orang dapat menemukan hukum-hukum yang mengatur semua perkembangan sosial. Simmel tidak melihat masyarakat sebagai bentuk organisme sebagaimana menurut Comte ataupun Spencer. Menurut Simmel masyarakat terdiri dari jaringan yang banyak liku-liku nya. Masyarakat hanyalah sebuah nama untuk sejumlah individu-individu yang dihubungkan oleh interaksi. Struktur superindividual yang lebih luas seperti halnya Negara, keluarga, klan, kota, atau persekutuan dagang hanyalah merupakan kristalisasi interaksi

Dalam kajian menggunakan interaksi 
simbolik, interaksi sosial yang dilakukan oleh buruh migran Indonesia adalah sebagai wujud dari masyarakat yang didalamnya muncul interaksi sosial yang terpola seperti halnya jaring laba-laba. Jaring laba-laba tersebut dianalogikan sebagai modal sosial yang dilakukan dengan perantara media sosial, yang dilakukan secara intens. Interaksi sosial yang dilakukan secara berkesinambungan oleh masing-masing buruh migran Indonesia yang berasal dari Kabupaten Tulungagung lama kelamaan akan menghasilkan jaring laba-laba sebagai analogi dari modal sosial yang dimiliki, semakin luas, semakin besar lingkupnya dan semakin menguat. Secara Sosiologis, interaksi ini dapat dikatakan bahwa buruh migran Indonesia mampu dikatakan membentuk sebuah masyarakat dalam sistem sosial yang lebih luas.

\section{KESIMPULAN}

Keterlibatan wanita di Kabupaten Tulungagung menjadi Buruh Migran Indonesia di beberapa Negara yang tersebar di Asia-Pasifik, dilakukan atas dasar keberanian dalam merubah nasib hidupnya dan melawan fatalisme sebagimana melekat pada masyarakat desa. Interaksi sosial yang dilakukan oleh buruh migran Indonesia melalui komunikasi virtual dengan perantara media sosial adalah bentuk dari Geometry of social space dalam kajian interaksi Simbolik. Interaksi sosial inilah yang menjadi modal utama dalam penguatan jaringan di dalam masyarakat sehingga buruh migran Indonesia mampu membentuk masyarakatnya sendiri dalam sistem sosial yang lebih luas.

\section{DAFTAR RUJUKAN}

Anggaunitakiranantika, dalam Candraningrum, Dewi (ed) (2015). Konstruksi Sosial Perempuan Buruh Migran Malang di HongKong: Social Prestige vs Lilitan Hutang dalamKebijakan Pembangunan Gender: Kepemimpinan, Ekologi, Kesehatan Reproduksi\& Seksual. Jakarta: Percetakan Jalasutra.

Appadurai, Arjun, (1993). Modernity at Large: Cultural Dimension of Globalization. Minnesota: University of Minnesota Press

Ford, Michelle, Parker,Lyn.(2008). Women \& Work in Indonesia. London: Routledge.

Field, John.(2010). Modal Sosial. Yogyakarta: Kreasi Wacana..

Geertz, Hildred.(1985). Keluarga Jawa. Jakarta: Grafiti Press.

Irianto, Sulistyowati.(2011). Akses Keadilan dan Migrasi Global Kisah Perempuan Indonesia Pekerja Domestik di Uni Emirat Arab. Jakarta: Yayasan Pustaka Obor Indonesia.
Jacques, Martin.(2009). When China Rules the World: The End of The Western World and The Birth of New Global Order. London: Penguin Press.

Newman, Lawrence W. (2000). Basic of Social Research: Qualitative and Quantitative Approaches. Essex: Pearson Education Limited

Plummer, Ken. (2011). Sosiologi The Basics. Jakarta: RajaGrafindo Persada.

Salmah, Emi dalam Candraningrum, Dewi (ed,) (2015). Strategi Penguatan Profesionalisme Buruh Migran Internasional asal NTB ke HongKong: Kajian Kebijakan Gender dalam Kebijakan Pembangunan Gender: Kepemimpinan, Ekologi, Kesehatan Reproduksi\& Seksual. Jakarta: Percetakan Jalasutra.

Sukesi, Keppi dalam Candraningrum, Dewi (ed), (2015). Dekonstruksi Budaya "Perempuan bukan Tiyang Wingking":Kasus Perempuan Buruh Migran dari Propinsi Jawa Timur dalam Kebijakan Pembangunan Gender: Kepemimpinan, Ekologi, Kesehatan Reproduksi\& Seksual. Jakarta: Percetakan Jalasutra.

Johnson, D.P.(1986). Teori Sosiologi Klasik dan Modern. Jilid 2. Jakarta Gramedia

Poloma, M. (1993). Teori Sosiologi Kontemporer. Jakarta: Raja Grafindo

Ritzer, G. dan Goodman, D.J., (2004). Sociological Theory. Edisi ke-6. New York: McGraw-Hill

Wallace, R.A. dan Wolf, A., (1980). Contemporary Sociological Theory: Continuing the Classical Tradition. Englewood: Prentice Hall

http://www.bnp2tki.go.id/stat_penempatan/inde ksdiakses pada 2 februari 2017, 23:12 